\title{
ANALISIS ISTINBÂT HUKUM AKAD PERKAWINAN MELALUI MEDIA ELEKTRONIK DALAM PERSPEKTIF HUKUM ISLAM
}

\author{
A. Fauzi Aziz \\ Institut Agama Islam Bani Fattah Jombang, Indonesia \\ E-mail: azizfauzi781@gmail.com
}

\begin{abstract}
Marriage is seen as a form worship which very sacred, at the present time, it has been the practice of marriages that use the facilities telephone or Cybernet, and also with the technology one step ahead, namely video teleconference. Where one party at a time doing this marriage ceremony, he was somewhere else that causes the marriage contract becomes ittihald al-majlis (merging chamber). With using a qualitative approach with Reserch Library obtained two different interpretations related to the ittịâd al-majlis. The Hanafiyah interpret it ijâb-qabûl to be done within the time contained in the marriage ceremony, not be done in two separate intervals. So, when guided by the interpretation of this argument, marriage ceremony via electronic media can be understood validity. The Shâfi'îyah stated that the united chamber required, to maintain continuity between ijâb and qabûl, at once must embody fulfillment of tasks of two witnesses. Because according to this argument, the two witnesses should be capable see with his eyes that $i j a ̂ b$ and qabûl it was actually spoken by two actors contract. So when referring to the second opinion, the practice of marriage ceremony via electronic media is not valid.
\end{abstract}

Keywords: Covenant of Marriage, Electronic Media, The Law of Islam 


\section{Pendahuluan}

Dalam hukum Islam dan ketentuan-ketentuan dalam Kompilasi Hukum Islam, tidak terdapat ketentuan khusus yang mengatur mengenai perkawinan dengan menggunakan alat bantu media elektronik. Dalam Kompilasi Hukum Islam, perkawinan tersebut sah bila dilakukan menurut hukum Islam, selain itu perkawinan tersebut harus memenuhi semua rukun nikah yang diatur pada Pasal $14 \mathrm{KHI}$, seperti adanya calon suami dan calon istri, wali nikah, dua orang saksi dan ijab kabul. Sedangkan sahnya pelaksanaan perkawinan itu sendiri bergantung sesuai atau tidaknya dengan dasar hukum yang ada dalam tuntunan Al-Qur'an dan Hadis, yang kemudian dijabarkan menjadi dasar hukum fikih yang lebih rinci dan sifatnya praktis, terlebih dalam menghadapi perubahan zaman.

Perkawinan melalui media elektronik baik melalui media telepon maupun video teleconference, yang menjadi titik permasalahannya ialah apakah pelaksanaan sigât akad baik ijab maupun kabul telah sesuai dengan syarat rukun keabsahannya.

Fenomena seperti ini menggelitik untuk dikaji dan dikomentari oleh para pakar hukum keluarga Islam di Indonesia. Karena praktek akad nikah jarak jauh dengan menggunakan media teknologi ini belum pernah sekalipun dijumpai pada zaman sebelumnya. Praktek akad nikah pada zaman Nabi dan para salaf al-sâlịh hanya menyiratkan diperbolehkannya metode tawkîl (mewakilkan), yakni pengganti pelaku akad apabila pihak pelaku akad (baik wali maupun mempelai pria) berhalangan untuk melakukannya.

\section{Fakta Peristiwa Akad Perkawinan melalui Media Elektronik}

Seperti halnya, kurang lebih satu dekade yang lalu, muncul peristiwa menarik dalam hal pelaksanaan akad nikah yang dilakukan secara tidak lazim dengan menggunakan media telepon. Kemudian status pernikahan ini dimohonkan pengesahannya melalui Pengadilan Agama Jakarta Selatan. Oleh Pengadilan Agama Jakarta Selatan status hukumnya dikukuhkan dengan dikeluarkannya Surat Putusan No. 1751/P/1989. ${ }^{1}$

Meski Pengadilan Agama Jakarta Selatan mengesahkan praktek semacam ini, namun putusan ini tetap dianggap riskan. Mahkamah

\footnotetext{
${ }^{1}$ http://m-alwi.com/hukum-transaksi-via-elektronik.html, diakses 8 Maret 2012
} 
Agung menegur hakim yang memeriksa perkara tersebut karena dikhawatirkan menimbulkan preseden yang tidak baik. ${ }^{2}$

Peristiwa yang serupa dengan itu terulang kembali. Kali ini praktek akad nikah dengan menggunakan fasilitas video teleconference. Teknologi video teleconference lebih mutakhir dari telepon, karena selain menyampaikan suara, teknologi ini dapat menampilkan gambar atau citra secara real time melalui jaringan internet. Hal ini seperti yang dipraktekkan oleh pasangan Syarif Abdurrahman Ahmad ketika menikahi Dewi Tarumawati pada 4 Desember 2006 silam. Ketika pelaksanaan akad nikah, sang mempelai pria sedang berada di Pittsburgh, Amerika Serikat. Sedangkan pihak wali beserta mempelai wanita berada di Bandung, Indonesia. Kedua belah pihak dapat melaksanakan akad nikah jarak jauh berkat layanan video teleconference dari Indosat.

Hal ini tidak berbeda dengan apa yang dilakukan oleh pasangan Sirojuddin Arif dan Iim Halimatus Sa'diyah. Dengan memanfaatkan teknologi ini, mereka melangsungkan akad nikah mereka pada Maret 2007 silam. Hanya perbedaannya adalah, kedua mempelai sedang berada di aula kampus Oxford University, Inggris, sedangkan wali mempelai berada di Cirebon, Indonesia ketika akad nikah dilangsungkan. ${ }^{3}$

\section{Kedudukan Ijab Kabul dalam Akad Nikah}

Pelaksanaan akad nikah didasarkan atas unsur saling ridla, atau rela sama rela. Oleh karena perasaan semacam ini adalah hal yang sangat tersembunyi, maka sebagai perwujudan keabstrakan dari akad nikah ini adalah dengan adanya ijab kabul. Karena itulah, ijab dan kabul adalah unsur mendasar bagi keabsahan akad nikah. ijab diucapkan oleh wali sebagai pernyataan rela menyerahkan anak perempuannya kepada calon suami, sedangkan kabul diucapkan oleh calon suami sebagai pernyataan rela mempersunting calon istrinya. Lebih jauh lagi, ijab berarti menyerahkan amanah Allah kepada calon suami, dan kabul berarti sebagai lambang kerelaan menerima amanah Allah tersebut. Dengan adanya ijab kabul ini, maka akan menjadi halal sesuatu yang tadinya haram. Dalam sebuah hadis Rasulullah saw bersabda bahwa dihalalkannya wanita sebagai istri, adalah dengan kalimat Allah.

2 Satria Effendi, Problematika Hukum Keluarga Islam Kontemporer, (Jakarta: Kencana, 2010), 2.

3 http://elfalasy88.wordpress.com/2010/11/30/akad-nikah-via-telepon/, diakses 8 Maret 2012 
Makna kalimat Allah dalam hadis di atas tidak lain ialah adanya ucapan ijab dan kabul itu sendiri. ${ }^{4}$ Sebab begitu pentingnya arti ijab dan kabul bagi keabsahan akad nikah, maka tersebutlah persyaratan-persyaratan ketat yang harus dipenuhi untuk mencapai keabsahan tersebut.

Diantaranya adalah ittịâd al-majlis (bersatunya majelis) dalam melakukan akad seperti yang disepakati oleh para ulama. Hanya saja dijumpai permasalahan tentang tafsiran dari ittị̧âd al-majlis itu sendiri di kalangan para ulama. Yang bila ditelusuri berujung pangkal pada dua penafsiran yang berbeda.

\section{Analisis Konsep Ittịhâd al-Majlis dalam Ijab Dan Kabul}

Dalam kitab al-Fiqh 'alâ al-Madhâhib al-Arba'ah mengutip kesepakatan ulama mujtahid mensyaratkan bersatunya majelis dalam ijab dan kabul. ${ }^{5}$ Dengan demikian apabila tidak bersatu antara majelis mengucapkan ijab dengan majelis mengucapkan kabulnya, maka akad nikah dianggap tidak sah. Akan tetapi setelah meneliti pendapat ulama, terdapat dua penafsiran terhadap apa yang dimaksud dengan ittị̂âd al-majlis (bersatu majelis), sebagai berikut:

\section{Pendapat Pertama}

Pertama, yang dimaksud dengan ittịâd al-majlis ialah bahwa ijab dan kabul harus dilakukan dalam jarak waktu yang terdapat dalam satu upacara akad nikah, bukan dilakukan dalam dua jarak waktu secara terpisah. ${ }^{6}$

Dalam arti misalkan bila ijab diucapkan dalam satu upacara, kemudian setelah upacara tersebut selesai kabul diucapkan pula pada upacara berikutnya, maka hal ini tidak sah. Walaupun dua upacara tersebut dilakukan dalam satu tempat yang sama secara berturut-turut, karena kesinambungan antara ijab dan kabul tidak terwujud maka hukumnya juga tidak sah.

Dengan demikian, adanya persyaratan bersatunya majelis adalah menyangkut keharusan kesinambungan waktu antara ijab dan kabul, bukan menyangkut kesatuan tempat. Karena, seperti dikemukakan di atas meskipun tempatnya bersatu, tetapi apabila dilakukan dalam dua waktu, dalam dua acara yang terpisah, maka kesinambungan antara pelaksanaan

\footnotetext{
${ }^{4}$ Satria Effendi, Problematika ........, 3.

5 'Abd al-Rahmân al-Jazîrîy, Al-Fiqh 'alâ al-Madhâhib al-Arba'ah. (Bairût: Dâr al-Ihyâ', tt), 20.

${ }^{6}$ Satria Effendi, Problematika ........, 3.
} 
ijab dan pelaksanaan kabul sudah tidak terwujud, dan oleh karena itu akad nikahnya tidak sah.

Senada dengan pendapat di atas, Sayyid Sâbiq dalam kitabnya fiqh alSunnab dalam menjelaskan arti 'bersatunya majelis' bagi ijab dan kabul, menekankan pada pengertian tidak boleh terputusnya antara ijab dan kabul. $^{7}$

\section{Uraian Maksud dari Pendapat Pertama}

Untuk menguatkan pendapat ini, satu contoh dikemukakan oleh alJazîrî tentang penjelasan pengertian ittiḩâd al-majlis (bersatunya majelis) dalam mażhab Hanafìy. Misalnya, seorang calon suami mengirim surat berisi akad nikahnya kepada pihak perempuan yang dikehendakinya. Sesampainya surat tersebut dan kemudian isinya dibacakan di depan wali perempuan dan para saksi dalam satu majelis yang sama, lalu wali calon istri langsung mengucapkan penerimaannya (kabul). ${ }^{8}$

Praktek akad nikah semacam ini menurut kalangan mażhab Hanafîy dianggap sah, dengan alasan bahwa pembacaan ijab calon suami yang tertulis di surat dan pengucapan kabul dari wali calon istri, didengar oleh dua orang saksi dalam majelis yang sama, tidak dalam dua upacara berturut-turut yang terpisah dari segi waktunya.

Dalam contoh di atas, ucapan ijab lebih dahulu diucapan oleh calon suami, dan setelah itu baru pengucapan kabul dari pihak wali calon istri. Praktek yang demikian ini diperbolehkan menurut mażhab Hanafìy. Karena ucapan akad yang diucapkan lebih dahulu disebut ijab, baik diucapkan oleh wali maupun oleh calon suami, dan ucapan akad yang disebutkan kemudian disebut kabul, baik diucapkan oleh calon suami maupun oleh wali calon istri.

Yang perlu ditekankan dalam pembahasan ini ialah bentuk akad nikah yang dicontohkan ini bukan berbentuk tawkîl (mewakilkan), karena yang didengar oleh para saksi adalah redaksi tertulis dalam surat calon suami yang dibacakan di depannya, dan pembaca surat dalam hal ini bukanlah sebagai wakil dari calon suami, karena surat tersebut tidak menyatakan hal yang demikian. Apa yang dibacakan dari surat itu tidak lain ialah redaksi langsung dalam bentuk tulisan calon suami

Pendapat di atas sejalan dengan penjelasan Sayyid Sâbiq bahwa akad nikah ghâib (salah seorang dari dua pihak tidak bisa hadir dalam majelis akad) itu mempunyai dua macam cara: pertama, dengan mengutus wakil,

\footnotetext{
${ }^{7}$ Satria Effendi, Problematika....., 4.

8 'Abd al-Rahmân al-Jazîrîy, Al-Figh ......., 20.
} 
dan kedua, dengan menulis surat kepada pihak lain untuk menyampaikan akad nikahnya. Bagi yang menerima surat, dan menyetujui atas isi surat itu, hendaklah mendatangkan para saksi kemudian di hadapan mereka redaksi surat itu dibacakan. Praktek semacam ini hukumnya sah, selama pengucapan kabulnya dilakukan langsung dalam satu majelis.' Dalam praktek tersebut jelas bahwa dua orang saksi itu hanya mendengar redaksi surat yang dibacakan di depannya, bukan dalam bentuk tawkêll (mewakilkan).

Berikut redaksi dalam kitab:

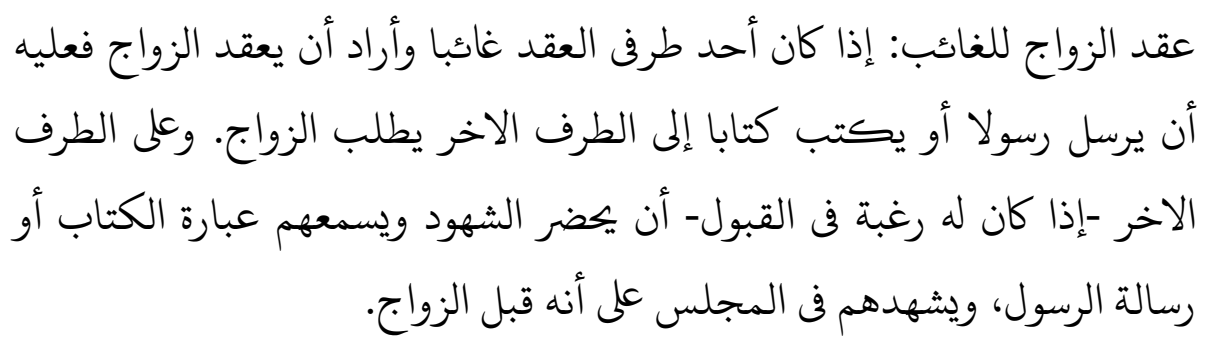

Suatu contoh lain misalnya seorang wali mengucapkan ijab di satu ruangan, sedangkan calon suami mengucapkan kabul di ruangan yang berbeda pada suatu upacara dan dalam waktu yang bersamaan, dibantu dengan alat pengeras suara seperti telepon, video teleconference dan lain-lain, maka kesinambungan antara ijab dan kabul jelas dapat terwujud.

Akan tetapi bila alat bantunya dengan memakai media elektronik yang hanya mampu mengirimkan suara saja seperti telepon, tanpa ada visualisasi gambar dari pihak lain, maka konsekuensi dari masalah ini ialah para saksi tidak dapat melihat pihak-pihak yang melakukan akad nikah.

Dalam hal ini Ibn Qudâmah, salah seorang ahli fiqh dari kalangan Hanafìy dalam kitabnya al-Mughnî menegaskan bahwa kesaksian dua orang buta dalam akad nikah adalah sah walaupun hanya sebatas kesaksian melalui suara saja. Menurutnya, kesaksian orang buta dapat diterima, selama ia dapat memastikan secara yakin bahwa suara yang ia dengar itu benar-benar diucapkan oleh para pelaku akad nikah. Pendapat Ibn Qudâmah tersebut diikuti oleh Sayyid Sâbiq dalam kitabnya Fiqh asSunnah. ${ }^{10}$

Dari keterangan di atas, dapat dipahami bahwa masalah esensi dari persyaratan bersatu majelis adalah menyangkut masalah keharusan kesinambungan antara ijab dan kabul. Kesinambungan ini adalah untuk

\footnotetext{
${ }^{9}$ Sayyid Sâbiq, Fiqh al-Sunnah, (Bairût: Dâr al-'Arabîy, 1997), 39.

${ }^{10}$ Satria Effendi, Problematika ......, 6.
} 
mewujudkan kepastian bahwa ijab dan kabul itu betul-betul sebagai manifestasi dari ungkapan rasa rela antara kedua belah pihak untuk mengadakan akad nikah.

Kabul yang langsung diucapkan setelah pengucapan ijab oleh wali, adalah diantara hal-hal yang menunjukkan kerelaan calon suami. Sebaliknya, adanya jarak waktu yang memutuskan ijab dan kabul, bisa jadi menunjukkan bahwa calon suami tidak lagi sepenuhnya rela untuk mengucapkan kabul, dan wali nikah dalam jarak waktu itu bisa jadi sudah tidak lagi pada pendiriannya semula, atau telah mundur dari kepastiannya. Oleh karena itu untuk lebih memastikan bahwa masing-masing masih dalam kerelaannya, maka disyaratkan adanya kesinambungan antara ijab dan kabul.

Dengan demikian, maka ijab dan kabul dipandang sebagai satu kesatuan yang tidak bisa dipisahkan. Untuk menjaga kesatuan itulah disyaratkan pula bersatu majelis dalam melakukan akad nikah. Persyaratan bersatu majelis, apabila yang dimaksudkan hanya untuk kesinambungan waktu, maka bersatunya tempat bukan satu-satunya untuk mewujudkan kesinambugan waktu.

Dan dari semua uraian pendapat di atas, bila digabungkan antara keabsahan mengucapkan ijab dan kabul melalui surat, dengan keabsahan kesaksian dua orang buta, maka syarat dua saksi harus mampu melihat pelaku ijab dan kabul bukan lagi hal yang penting. Dengan demikian, ketentuan kedua pelaku akad untuk hadir dan melaksanakan akad dalam satu ruangan dengan alasan agar dapat dilihat oleh para saksi, tidak lagi menjadi syarat bagi keabsahan akad nikah.

\section{Pendapat Kedua}

Pendapat kedua atas tafsiran ittihâd al-majlis adalah pendapat yang menyatakan bahwa bersatu majelis disyaratkan, untuk menjaga kesinambungan antara ijab dan kabul, sekaligus harus mewujudkan pemenuhan tugas dua orang saksi. Karena menurut pendapat ini, kedua saksi harus mampu melihat dengan mata kepalanya bahwa ijab dan kabul itu betul-betul diucapkan oleh kedua pelaku akad. ${ }^{11}$

\section{Uraian Maksud dari Pendapat Kedua}

Salah satu syarat sah akad nikah adalah dihadiri oleh dua orang saksi. Dan tugas dua orang saksi, seperti yang disepakati oleh para ulama adalah untuk memastikan secara yakin keabsahan ijab dan kabul dari segi

\footnotetext{
${ }^{11}$ Satria Effendi, Problematika ......, 6.
} 
redaksinya, maupun dari segi kepastian bahwa antara ijab dan kabul itu diucapkan oleh kedua belah pihak. ${ }^{12}$

Dimaklumi bahwa keabsahan suatu redaksi memang dapat dipastikan cukup dengan mendengarkannya saja. Tetapi kepastian bahwa redaksi sungguh-sungguh diucapkan oleh kedua pelaku akad, hanya bisa ditentukan dengan melihat para pihak secara langsung. Pendapat inilah yang dipegangi oleh kalangan ulama-ulama mujtahid, terutama kalangan Shâfi'îyah.

Sebagai konsekuensi dari pendapat ini, membuat kesaksian orang buta tidak dapat diterima untuk akad nikah. Hal ini seperti yang dinyatakan oleh ulama Shâfi'îyah Ibnu Hajar al-Haitamîy, (wafat tahun 973 H.) dalam kitabnya Tubfat al-Mubtâj. Ibnu Hajar menolak kesaksian orang buta dengan alasan bahwa kesaksian atas akad haruslah berdasarkan penglihatan dan pendengaran. Sebab kesaksian orang buta sama saja seperti kesaksian seseorang yang berada dalam kegelapan. Kedua macam kesaksian ini tidak sah, sebab para saksi sama-sama tidak dapat melihat para pelaku akad. Dengan ketidakmampuan ini, maka tidak akan timbul kepastian bahwa ijab dan kabul sungguh-sungguh diucapkan oleh para pelaku akad. ${ }^{13}$

Berikut redaksi kitabnya:

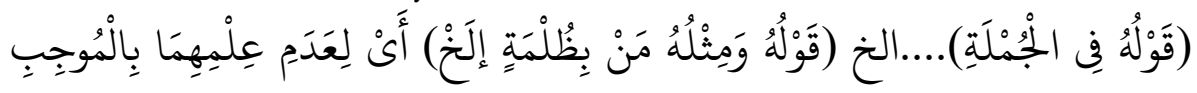

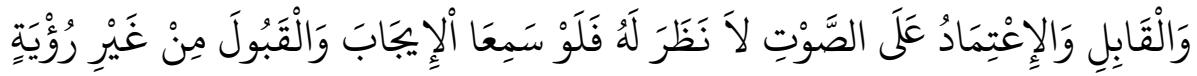

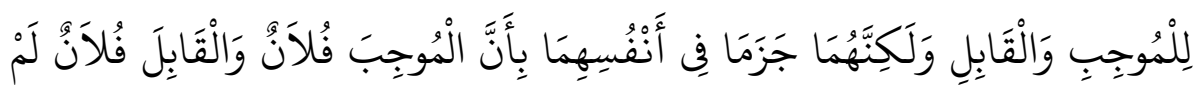

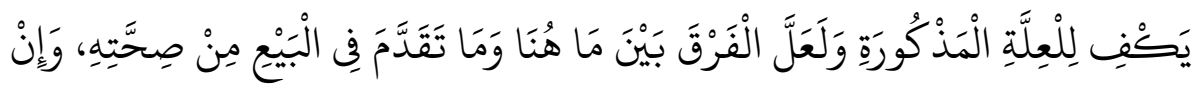

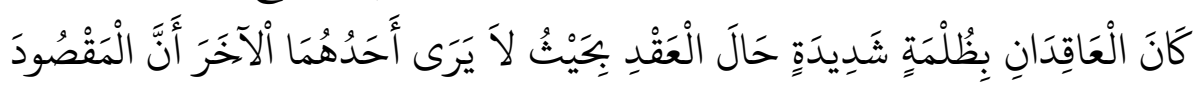

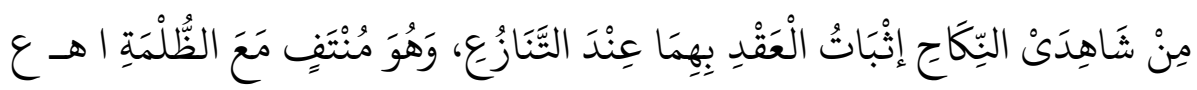

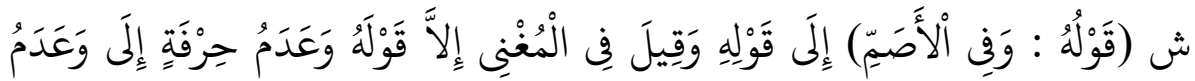

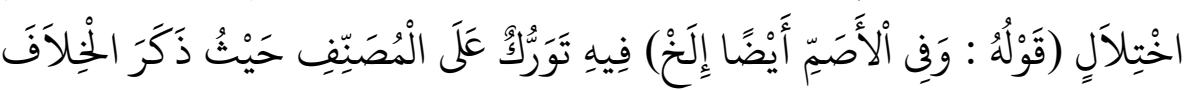

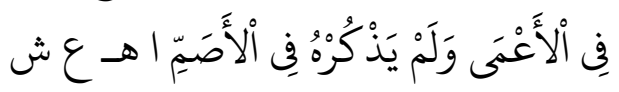

\footnotetext{
12 Satria Effendi, Problematika ......, 6.

13 Ibnu Hajar al-Haitamîy, Tụfat al-Mụ̣tâj, (Dalam al-Maktabah al-Syâmilah), 384.
}

109 Fauzi Aziz - Analisis Istinbât Hukum Akad Perkawinan Media Elektronik 
Shaikh 'Abd al-Ḥamîd al-Syarwânîy, dalam komentarnya terhadap ketetapan pendapat Ibnu Hajar menyatakan pendapatnya bahwa kesaksian orang dalam gelap tidak sah, karena tidak dapat mengetahui kedua orang yang sedang melakukan akad. Sedangkan berpegang kepada suara saja tidaklah memadai. Seandainya kedua orang saksi mendengar ijab dan kabul, tetapi tidak melihat kedua orang yang mengucapkannya, meskipun dua orang saksi mengetahui betul bahwa ijab dan kabul adalah suara dari kedua belah pihak, namun akad nikahnya tetap dianggap tidak sah, dengan alasan tidak dilihat dengan mata kepala (al-mu'ayyanab). ${ }^{14}$

Berikut redaksi kitabnya:

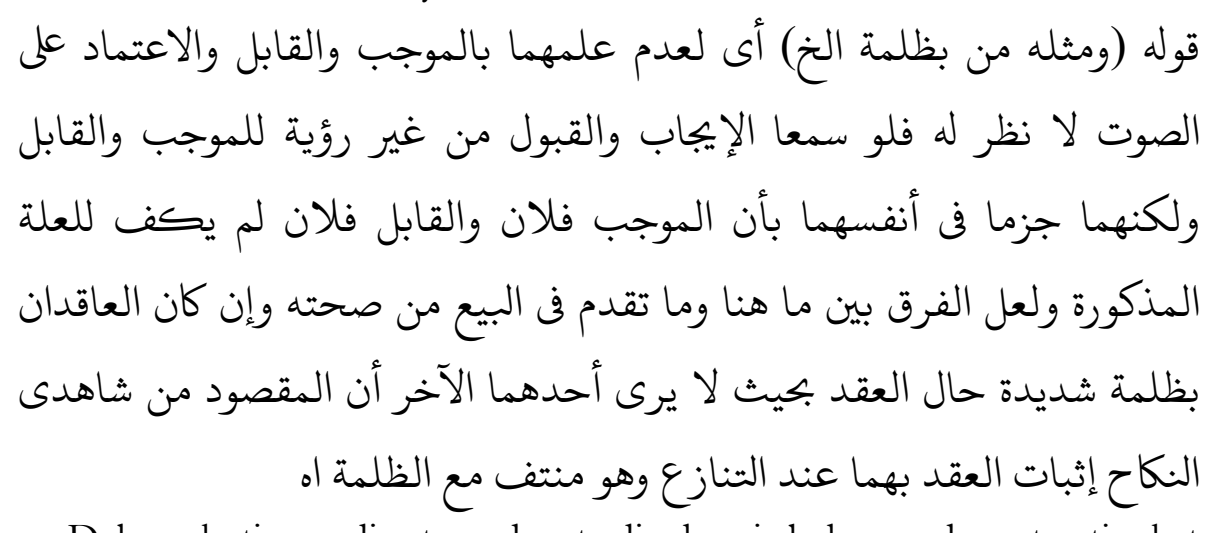

Dalam kutipan di atas, dapat dipahami bahwa ada satu tingkat keyakinan para saksi yang harus dicapai dalam kesaksian akad nikah untuk mewujudkan keabsahan. Meskipun suatu redaksi dapat diketahui siapa pembicaranya dengan cara mendengarkan suara saja, namun bobotnya tidak akan sampai ke tingkat keyakinan apabila dilihat pengungkapannya dengan mata kepala. Sedangkan dalam akad nikah, tingkat keyakinan semacam inilah yang diperlukan.

Pandangan semacam ini adalah implementasi dari sikap para ulama Shâfi'îyah yang selalu bersikap hati-hati (ỉbtiyât) dalam menetapkan suatu hukum, lebih-lebih dalam masalah akad nikah. karena akad nikah berdampak pada halalnya sesuatu yang awalnya diharamkan.

Oleh karena kesaksian harus didasarkan atas pendengaran dan penglihatan, maka menurut pandangan ini ijab dan kabul melalui surat dan tanpa mewakilkan, hukumnya tidak sah. Oleh karena itu pula Imâm Nawawìy dalam kitabnya al-Majmû' mencontohkan sebuah perumpamaan sebagai berikut: apabila salah seorang dari dua pihak yang melakukan

${ }^{14}$ Shaikh 'Abd al-Hamîd al-Sharwânîy, Hawâshî al-Sharwânî, (Bairût: Dâr al Fikr, t.t.), Dalam Maktabah al-Syâmilah, vol. VII, 228. 
akad nikah mengucapkan ijabnya dengan cara berteriak dari tempat yang tidak dapat dilihat, dan teriakan itu didengar oleh pihak lain dan segera mengucapkan kabulnya, maka akad nikah seperti ini hukumnya tidak sah. $^{15}$

Dari pemahaman di atas secara tegas dapat diketahui bahwa persyaratan bersatu majelis oleh kalangan Shâfi'îyah bukan hanya dimaksudkan untuk menjaga kesinambungan waktu, tetapi juga mengandung persyaratan lain, yaitu al-mu'ayyanah. Yakni kedua pelaku akad sama-sama hadir dalam satu tempat. Sebab dengan cara ini (almu'ayyanah) persyaratan dapat melihat secara nyata dalam pengucapan ijab dan kabul dapat diwujudkan.

Di samping hal-hal tersebut di atas, hal yang perlu ditekankan dalam pandangan madhhab Syâfi'îy ialah bahwa masalah akad nikah tergolong perbuatan yang bernilai táabbudîy yang harus diterima apa adanya. Dengan demikian, maka tata laksananya harus bersifat tauqifizyah, dalam arti harus terikat dengan pola yang telah diwariskan Rasulullah untuk umatnya. Itulah sebabnya mengapa golongan Shâfi'îyah mensyaratkan ijab kabul lafaznya harus seperti yang terdapat dalam nass, seperti lafaz nikeâh atau tazwîj..$^{16}$

Dari keterangan di atas, dapat diketahui pokok-pokok pedoman golongan Shâfi'îyah dalam hal ini, yaitu:

Pertama, kesaksian harus didasarkan atas penglihatan dan pendengaran. Oleh sebab itu kesaksian orang buta tidak dapat diterima. Untuk memenuhi persyaratan itu, maka disyaratkan bersatu majelis, dalam arti bersatu tempat secara fisik. Karena dengan itu, persyaratan almu'ayyanah dalam arti dapat dilihat secara fisik, dapat dipenuhi. Pandangan ini erat hubungannya dengan sikap hati-hati dalam masalah akad nikah.

Kedua, akad nikah mengandung arti ta'abbudîy. Maka pelaksanaannya harus terikat dengan apa yang dicontohkan oleh Rasulullah saw.

Oleh karena akad nikah mengandung arti ta'abbudîy, maka pengembangan lewat analogi atau qiyâs tidak dapat diterima dalam pelaksanaannya.

\footnotetext{
15 Satria Effendi, Problematika....., 7.

${ }^{16}$ Satria Effendi, Problematika....., 8.
}

111 Fauzi Aziz - Analisis Istinbât Hukum Akad Perkawinan Media Elektronik 


\section{Analisis Kedua Pendapat}

Dua pandangan tersebut di atas membawa kepada dua kesimpulan tentang beberapa kasus mengenai pengesahan akad nikah melalui media elektronik sebagai berikut:

Pertama, Apabila berpedoman kepada penafsiran dari pendapat pertama, maka akad nikah melalui media elektronik berhukum sah. Seperti dikemukakan terdahulu, persyaratan bersatu majelis oleh pendapat ini dipahami sebagai adanya kesinambungan waktu antara ijab dan kabul. Kesinambungan waktu antara ijab dan kabul, dapat diwujudkan dari dua tempat yang berbeda dengan memakai alat penyambung dan pengeras suara.

Dalam praktek akad nikah melalui media elektronik, persyaratan tersebut jelas dapat dipenuhi. Karena para saksi yang ditugaskan untuk itu, dapat memastikan dengan melihat wali perempuan mengucapkan ijabnya, dan sebaliknya para saksi yang non formal (seperti: berada di Amerika) dapat memastikan dengan cara melihat calon suami mengucapkan kabulnya.

Dengan cara demikian, persyaratan kesinambungan waktu dapat diwujudkan dan dipastikan dengan alat penghubung pengeras suara dan bisa juga bergambar (media elektronik), dan persyaratan para saksi harus yakin dan melihat pelaku akad juga telah dipenuhi walaupun terdapat dua kelompok saksi di tempat yang berbeda.

Adanya kekhawatiran pemalsuan suara sudah menjadi tidak berarti lagi, ketika para saksi formal yang berada di Indonesia dan para saksi non formal yang berada di Amerika sama-sama dapat dihadirkan oleh pihak Pencatatan Perkawinan dan serentak memastikan terjadinya ijab dan kabul antara kedua belah pihak, dan kedua belah pihak pun tidak mengingkari kesaksian tersebut.

Kedua, Bila dilihat dengan kaca mata pendapat Shâfi'îyah, maka jelas bahwa praktek akad nikah melalui media elektronik ini tidak sah. Untuk lebih jelas lagi, berikut perbandingan antara praktek akad nikah tersebut, dengan pokok-pokok pedoman kalangan Shâfi'îyah, sebagai berikut:

\begin{tabular}{|l|l|}
\hline \multicolumn{1}{|c|}{$\begin{array}{c}\text { Pokok-pokok Pedoman } \\
\text { Kalangan Shâfi'îyah }\end{array}$} & \multicolumn{1}{c|}{$\begin{array}{c}\text { Praktek Akad Nikah yang } \\
\text { Terjadi }\end{array}$} \\
\hline $\begin{array}{l}\text { Para saksi harus dapat melihat } \\
\text { pelaku akad nikah (al-mu'ayyanah) } \\
\text { dalam arti berhadap-hadapan } \\
\text { secara fisik. }\end{array}$ & $\begin{array}{l}\text { Para saksi yang berada di Indonesia } \\
\text { hanya mendengar suara atau juga } \\
\text { melihat gambar calon suami di } \\
\text { tempat lain (seperti: Amerika) } \\
\text { dengan tidak dapat berhadap- } \\
\text { hadapan secara fisik, begitu juga }\end{array}$ \\
\hline
\end{tabular}




\begin{tabular}{|c|c|}
\hline & sebaliknya. \\
\hline $\begin{array}{l}\text { Persyaratan ittihâd al-majlis } \\
\text { (bersatu majelis) harus dengan } \\
\text { cara bersatu tempat untuk } \\
\text { mencapai al-mu'ayyanah. }\end{array}$ & $\begin{array}{l}\text { Syarat al-mu'ayyanah tidak tercapai } \\
\text { kecuali menggabungkan kesaksian } \\
\text { dua kelompok saksi Indonesia- } \\
\text { Amerika. }\end{array}$ \\
\hline $\begin{array}{l}\text { Masalah akad nikah berunsur } \\
\text { ta'abbudîy, karena itu harus sesuai } \\
\text { dengan contoh Nabi saw. }\end{array}$ & $\begin{array}{l}\text { Praktek penyaksian akad dengan } \\
\text { dua kelompok saksi yang berbeda } \\
\text { tidak pernah terjadi pada zaman } \\
\text { Nabi saw. }\end{array}$ \\
\hline
\end{tabular}

Ketiga, Mengenai cara akad nikah yang sesuai dengan contoh Nabi SAW, hal ini dapat disimpulkan hanya ada dua macam. Yang pertama adalah calon suami hadir dengan wali calon istri dalam satu tempat untuk melaksanakan akad. Yang kedua calon suami mengutus wakil yang dipercaya untuk mengakadkan dirinya bila ia tidak dapat menghadiri akad tersebut.

Contoh akad nikah berwakil terdapat dalam beberapa hadis, diantaranya sebagai berikut:
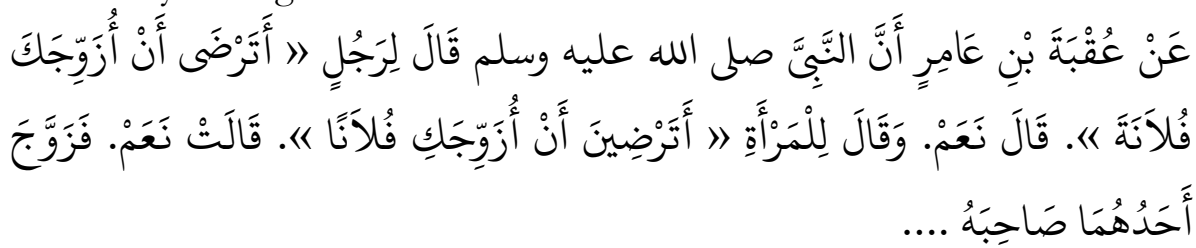

Artinya: Hadis riwayat Ab̂̂ Dâwud, dari 'Uqbah ibn 'Âmir, yakni Rasulullah pernah berkata kepada seorang laki-laki, "Apakah engkau rela untuk. saya kawinkan dengan perempuan fulânâh?." Laki-laki itu menjawab, "bersedia". Kemudian Rasulullah berkata pula kepada perempuan yang dimaksud, "Apakah kamu bersedia untuk saya kawinkan dengan lakilaki fulân? Perempuan itu menjawab, "Bersedia". Kemudian Rasulullah menik.abkean keduanya. ${ }^{17}$

Hadis tersebut menunjukkan bahwa laki-laki itu menyetujui untuk dikawinkan oleh Rasulullah, maksudnya Rasulullah bertidak sebagai wakilnya dalam melakukan akad nikah. Oleh karena hadis tersebut menunjukkan arti tawkîl (mewakilkan) seperti demikian, maka Sayyid Sâbiq dalam kitabnya Fiqh al-Sunnah mengemukakan hadis tersebut sebagai dalil bagi keabsahan berwakil dalam mengakadkan nikah. Sayyid Sâbiq menyatakan, bahwa dalam praktek tersebut Rasulullah bertindak

17 'Abû Dâwud, Sunan Abî Dâwud, (Bairût: Dâr al-Kitâb al-'Arabî, tt.), dalam Maktabah al-Syâmilah, vol. II, hadits ke-2119, 203.

113 Fauzi Aziz - Analisis Istinbạt Hukum Akad Perkawinan Media Elektronik 
sekaligus sebagai wakil dari kedua belah pihak, yang menurutnya praktek seperti itu adalah sah. Maksudnya, pada waktu itu Rasulullah bertindak sebagai wali $\hat{a} \mathrm{~mm}$ bagi wanita dimaksudkan, dan sekaligus wakil dari calon suami dalam mengucapkan kabulnya. ${ }^{18}$

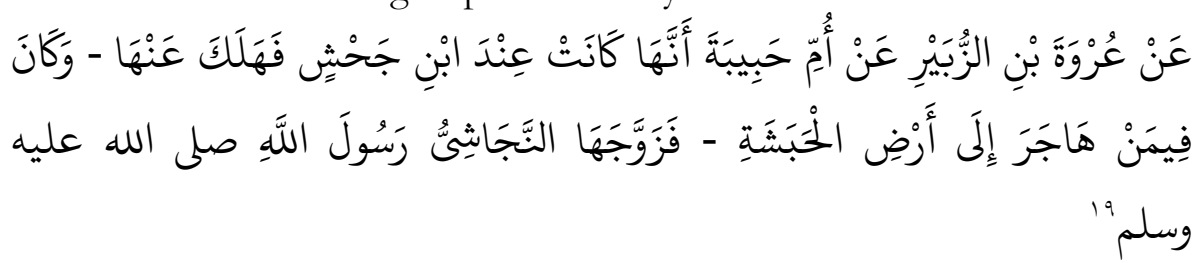

Artinya: Hadis riwayat Abû Dâwud yang menceritakan bahwa Ummu Habîbah yang setelah suaminya bernama 'Abdullahb bin Jahsy wafat, lalu ia ikut diantara kelompok yang berhijrah ke Habasyah. Maka kemudian ia dikawinkan dengan Rasulullah oleh al-Najasyiy.

Menurut Sayyid Sâbiq, yang bertindak sebagai wakil Rasulullah dalam akad perkawinan tersebut ialah 'Amru ibn 'Umayyah al-Damarîy yang telah terlebih dahulu menerima tawkîl dari Rasulullah. ${ }^{20}$

Kesimpulan tersebut sesuai dengan kesimpulan Abû Isḥâq al-Shîrazîy, seorang ulama Shâfi'îyah dalam kitabnya al-Muhadhdhab. Oleh karena itu, Sayyid Sâbiq dan al-Shîrazîy menjadikan hadis tersebut sebagai dalil bagi keabsahan bertawkîl.

Dari kedua Hadist di atas dapat disimpulkan bahwa Rasulullah mencontohkan apabila calon suami tidak sempat hadir, maka jalan keluarnya adalah dengan bertawkîl. ${ }^{21}$

Keempat, Bila mengikuti pendapat Shâfi'îyah, maka andaikata di kemudian hari terjadi peristiwa akad nikah jarak jauh, dimana para pihak dapat didengar suaranya sekaligus dapat dilihat gambarnya, maka praktek seperti itu tetap dinyatakan tidak sah. Sebab syarat al-mu'ayyanah atau berhadap-hadapan secara fisik tidak dapat terpenuhi. Karena dalam contoh ini yang dapat dilihat hanyalah gambarnya, bukan fisik jasmani seperti yang terdapat dalam sunah Rasul.

Kelima, Perlu diakui, bahwa pemahaman Shâfi îyah dalam hal ini terasa amat kaku, sehingga dengan demikian masalah pelaksanaan akad nikah tidak bisa berkembang.

\footnotetext{
18 Sayyid Sâbiq, Fiqh al-Sunnah......, 139.

19 'Abû Dâwud, Sunan Abî Dâwud, (Bairût: Dâr al-Kitâb al-'Arabî, tt.) vol. II, 2088.

${ }^{20}$ Sayyid Sâbiq, Fiqh al-Sunnah......, 139.

21 'Abû Dâwud, Sunan...., 2088.
} 
Keenam, Kekakuan dan keketatan Shâfi'îyah dimaklumi sebagai sikap kehati-hatian (i.btiyât), untuk membendung praktek-praktek akad nikah yang tidak pasti.

Ketujuh, Dua kesimpulan hukum tersebut di atas, dapat dijadikan alternatif mana yang akan dipilih, selama belum ada suatu ketegasan pendapat mana yang diberlakukan di peradilan Agama. Bila sudah ada ketegasan pendapat mana yang disepakati untuk diberlakukan (baik berwujud undang-undang atau peraturan), maka umat Islam wajib terikat dengan undang-undang atau peraturan yang disepakati. Hal ini sesuai dengan kesepakatan ulama, bahwa bila sudah ada ketetapan yang akan diberlakukan di peradilan, maka selain ketetapan itu tidak berlaku lagi bagi umat Islam. 


\section{Kesimpulan}

Setelah melakukan penelitian dan pembahasan pada bab-bab sebelumnya, untuk mengakhiri pembahasan ini penulis akan menutup dengan mengambil kesimpulan:

Pertama, Praktek akad perkawinan melalui media elektronik yang pernah terjadi adalah dengan dua bentuk cara. Pertama melalui telepon, yakni media elektronik yang hanya mampu mengirimkan suara saja pada waktu proses terjadinya akad nikah. Yang kedua adalah dengan video teleconference. Alat ini selain bisa menghubungkan suara, juga dapat menampilkan gambar atau citra secara realtime dari masing-masing pihak yang melakukan akad nikah melalui jaringan internet.

Kedua, Tinjauan hukum Islam terhadap akad perkawinan melalui media elektronik terdapat dua pendapat. Pertama, akad nikah ini dihukum sah sesuai dengan pandangan kalangan Hanafiyah. Pendapat ini menafsirkan atas syarat ittihâd al-majlis (bersatunya majelis) adalah menyangkut keharusan kesinambungan waktu antara ijab dan kabul, bukan menyangkut kesatuan tempat. Pendapat kedua, menyatakan bahwa akad perkawinan ini tidak sah. Hal ini sesuai dengan pandangan ulama Shâfi'îyah. Pendapat ini menyatakan bahwa bersatu majelis disyaratkan untuk menjaga kesinambungan antara ijab dan kabul, sekaligus harus mewujudkan pemenuhan tugas dua orang saksi. Menurut pendapat ini, kedua saksi harus mampu melihat dengan mata kepalanya bahwa ijab dan kabul itu betul-betul diucapkan oleh kedua pelaku akad. 


\section{Daftar Pustaka}

Anshary, M. Hukum Perkawinan Di Indonesia; Masalah-Masalah Krusial. Yogyakarta: Pustaka Pelajar, 2010. Cet. I.

Basyir, Ahmad Azhar. Hukum Perkawinan Islam. Yogyakarta: UII Press 2007.

Dâwud, 'Abû. Sunan Abî Dâwud. Bairût: Dâr al-Kitâb al-'Arabî, t.t. Vol. II. ke-2119. Dalam Al-Maktabah al-Syâmilah.

Departemen Agama Republik Indonesia. Al-Qur'an dan Terjemahnya. Jakarta: PT Syamil Cipta Media, 2004.

Effendi, Satria. Problematika Hukum Keluarga Islam Kontemporer. Jakarta: Kencana, 2004.

http:/ / elfalasy88.wordpress.com/2010/11/30/akad-nikah-via-telepon/, diakses pada 8 Maret 2012

http://m-alwi.com/hukum-transaksi-via-elektronik.html, diakses pada 8 Maret 2012

Jazîrîy (al), 'Abd al-Rahmân, Al-Fiqh 'alâ al-Madhâhib al-Arba'ah. Bairût: Dâr al-Iḥyâ', t.t.

Sâbiq, Sayyid. Fiqh al-Sunnah. Bairût: Dâr al-'Arabîy, 1997.

Silmîy (al), Muḥammad ibn 'Isâ Abû 'Isâ al-Turmuzîy. Al-Jâmi' al-Sabịh alTurmudhîy. Dalam al-Maktabah al-Syâmilah. Vol. IV.

Soemiyati, Ny. Hukum Perkawinan Islam dan Undang-Undang Perkawinan. Yogyakarta: Liberty, 2007. Cet. VI.

Syarifuddin, Amir. Hukum Perkawinan Islam di Indonesia. Jakarta: Kencana Media Group, 2009. Cet. III.

Tihami dan Sohari Sahrani. Fiqih Munakahat; Kajian Fiqib nikah Lengkap, Jakarta: Rajawali Pers, 2009.

Tim Redaksi Fokus Media. Kompilasi Hukum Islam. Bandung: Fokus Media, 2007. Cet. 2.

Undang-Undang Perkawinan Nomor 1 Tahun 1974. Semarang: Beringin Jaya, t.t.

Undang-Undang RI Nomor 11 Tabun 2008 Tentang Informasi dan Transaksi Elektronik. Surabaya: Kesindo Utama, 2010. Cet. II. 